\title{
Selection of Magnesium Alloy by MADM Methods for Automobile Wheels
}

\author{
D.Sameer Kumar ${ }^{\mathrm{a} *}$, K.N.S.Suman ${ }^{\mathrm{b}}$ \\ ${ }^{a}$ Department of Mechanical Engineering, R.V.R. \& J.C. College of Engineering, Guntur, INDIA. \\ ${ }^{a}$ Department of Mechanical Engineering, Andhra University College of Engineering, Visakhapatnam, INDIA
}

\begin{abstract}
The selection of suitable material plays fundamental and vital role in product development as each material possesses individual characteristics that contribute many aspects to suit the particular application. A wrong selection of materials favours huge cost contribution as well as product failure. Hence among the various available materials the selection of a particular becomes difficult. A better methodology is more and more needed for the selection of material. Multi Attribute Decision Making (MADM) methods based on mathematical models provide a ranking to the different alternatives, there by the decision making become easier. This paper presents the selection of Magnesium alloy material to use in automotive wheel applications using MADM methods. The influence of weighting factors has also been discussed.
\end{abstract}

Index Terms: Alloy wheels, Magnesium alloys, Decision making, MADM methods, Material Selection, AHP, TOPSIS, entropy method.

(C) 2014 Published by MECS Publisher. Selection and/or peer review under responsibility of the Research Association of Modern Education and Computer Science.

\section{Main text}

Automotive industry in India is growing prominently and has shown its impact globally. It is well known fact that the usage of optimal and correct resources will enhance the profits and product development phase plays a prominent role in evaluating product performance. As such product development should contain material selection, design and manufacturing process to meet Low Cost, High Performance and Quality.

A reduction in mass/weight of a vehicle is the critical objective to be considered without compromising other attributes like size, acceleration, $\mathrm{CO}_{2}$ emissions, dynamic stability and surface integrity [1]. Many researchers tried different methods like to use alternate fuels, alternate materials, power train enhancements, aerodynamic

* Corresponding author. Tel.: +91-9441651072;

E-mail address: me2meer@gmail.com 
improvements etc. to improve the standards of the vehicle [2]. Use of alternate materials is the simplest and cost effective among the others. In the selection of particular material, the engineer usually applies trial and error methods or produce their knowledge and experience which may not valid every time. So an efficient and organized approach is needed to choose the best material. Hence the focus is on the material for automotive wheels. Magnesium have been chosen for this purpose.

One of the primary advantages of magnesium is its density. It is approximately $2 / 3^{\text {rd }}$ of that of aluminum, $1 / 4^{\text {th }}$ of zinc, and $1 / 5^{\text {th }}$ of steel. The abundance of Magnesium on the earth is considered to be $4^{\text {th }}$ highest following iron, oxygen and silicon. But magnesium has disadvantages like corrosion, oxidation and melts at low temperatures. Due to its low mechanical strength, Magnesium was alloyed with $\mathrm{Al}, \mathrm{Zn}$, manganese, rare earths, thorium, zirconium, to make them most important materials for applications, where weight reduction is important [3].

The selection of alloying elements of Magnesium depends on the functional requirement, availability of alloying element, manufacturing capabilities, cost and customer requirement. So there are many Magnesium alloys to choose to do the same function. Hence decision maker faces a problem to assess the particular material among different options available.

MADM methods relies on the principles of mathematics are being widely used to select the best among the different alternatives [4]. R.V. Rao and others gave a wide publicity to these algorithms by conducting a series of workshops in india and its usage in various fields [5]. Dilip Rai et al. and solved material selection problem for flywheel and sailing boat using Vlse Kriterijumska Optimizacija Kompromisno Resenje (VIKOR) and ELECTRE II methods, and relative ranking performances were compared [6]. Few combinations of these algorithms were also proposed to make them more convenient in achieving good quality solution. Ali Jahan discussed the selection of parameters and weights identification along with MADM procedures and application [7]. A material selection problem with 8 alternates and 10 attributes with the effect of weightage factors are considered in this study.

\section{Problem Formulation}

Wheel is a most important component in an automobile. It support and bear the entire load and suffers not only with the vertical force but also the irregular and sudden forces resulting from braking, road bumps, car's ride, cornering, and all shocks in the process of moving on an uneven road. Due to high speed rotation, its quality has a huge impact on wheel stability, handling and their characteristics [8].

In real world, alloy wheels are made of Steel, Aluminium or Magnesium alloys. Among the other materials, Magnesium is the best choice because of lower density and widely used in race cars. The problem involves identification of different magnesium alloy materials that are used in the manufacturing of alloy wheels and to select the best among them [1-3, 10,11]. A survey has been made on Mg alloys and properties on the web [1422] and similar properties of all alloys are tabulated. Eight Magnesium alloys with ten important properties (Density - Physical Property, UTS, YTS, FS, Impact, Hardness, \% Elongation - Mechanical Properties, Thermal Conductivity, Specific heat, CTE - Thermal Properties) are considered and shown in table1.

From table 1, the decision making to select the particular is complex because AM50 posses superior density value but in view of YTS, AZ31 is preferable. When fatigue Strength is the main criterion AZ 91 is a good choice. EZ 33 almost matches AZ91 in \% elongation while density is low for EZ33. ZE63 possesses good UTS and ZC63 in terms of Thermal Conductivity. Alloys like EZ, ZE etc are good in strength but contain rare earth additions which are costly. Similarly, every material is having its own positives and negatives. Hence the decision maker has to compare all the materials regarding each aspect and has to judge the best one. So the proposed approach is trying to find the best alloy, satisfying the requirements. 
Table 1. Magnesium alloy Materials and its properties

\begin{tabular}{|c|c|c|c|c|c|c|c|c|c|c|c|}
\hline S.No & Material & $\begin{array}{l}\text { Density } \\
\left(\mathrm{g} / \mathrm{cm}^{3}\right)\end{array}$ & $\begin{array}{c}\text { Thermal } \\
\text { Conductivity } \\
(\mathrm{W} / \mathrm{mK})\end{array}$ & $\begin{array}{c}\text { UTS } \\
\text { (Mpa) }\end{array}$ & $\begin{array}{c}\text { YTS } \\
(\mathrm{Mpa})\end{array}$ & $\begin{array}{c}\text { Fatigue } \\
\text { Strength } \\
\text { (Mpa) }\end{array}$ & $\underset{(J)}{\text { Impact }}$ & $\begin{array}{c}\text { Hardness } \\
(\mathrm{BHN})\end{array}$ & $\begin{array}{c}\% \\
\text { Elongation } \\
\text { in } 50 \mathrm{~mm}\end{array}$ & $\begin{array}{c}\text { Specific } \\
\text { Heat } \\
\left(\mathrm{J} / \mathrm{g}-{ }^{\circ} \mathrm{C}\right)\end{array}$ & $\begin{array}{c}\text { Coeff . of } \\
\text { Thermal } \\
\text { Expansion } \\
(\mu \mathrm{m} / \mathrm{m}-\mathrm{C})\end{array}$ \\
\hline 1 & AZ91 & 1.81 & 72.7 & 230 & 150 & 97 & 2.7 & 63 & 3 & 0.8 & 26 \\
\hline 2 & AM60 & 1.79 & 62 & 241 & 131 & 80 & 2.8 & 65 & 13 & 1 & 26 \\
\hline 3 & AM50 & 1.77 & 65 & 228 & 124 & 75 & 2.5 & 60 & 15 & 1.02 & 26 \\
\hline 4 & AZ31 & 1.771 & 96 & 260 & 200 & 90 & 4.3 & 49 & 15 & 1 & 26 \\
\hline 5 & ZE41 & 1.84 & 113 & 205 & 140 & 63 & 1.4 & 62 & 3.5 & 1 & 26 \\
\hline 6 & EZ33 & 1.8 & 99.5 & 200 & 140 & 40 & 0.68 & 50 & 3.1 & 1.04 & 26.4 \\
\hline 7 & ZE63 & 1.87 & 109 & 295 & 190 & 79 & 2.3 & 75 & 7 & 0.96 & 27 \\
\hline 8 & ZC63 & 1.87 & 122 & 240 & 125 & 93 & 1.25 & 60 & 4.5 & 1 & 26 \\
\hline
\end{tabular}

\section{Methodology}

The following steps are to be adopted while using the MADM Methods.

1. Identifying the weightage to each attribute

2. Implementing different methodologies.

\subsection{Identifying the weightage of each attribute}

Among various attributes, identify the weightage of each attribute i.e. the relative importance of the parameter with respect to other. The weightage factors play a major role in deciding the fate of the material has to be decided as to choose or not to choose. The weighting factors plays a significant role in the ranking of each material depends on the relative importance made by the decision maker. The problem proposed here consists of implementing mean weighting, randomized and entropy based weightage factors to each attribute and to decide the selection more precisely.

\subsection{Implementing Different Methodologies}

Whenever the weightages are decided by the decision maker, a class of different methodologies can be implemented. Simple procedure of MADM methods is explained below.

(i) Writing down the alternatives, attributes

(ii) Choosing weightages of relative importance of each attribute

(iii) Normalize the table based on beneficiary and non beneficiary varibles

(iv) Calculating the measure of performance (mop) of each alternate using different MADM methodologies.

(v) Based on mop, ranking the alternates.

Even though there are more number of MADM methods, a few have higher potential to solve in the manufacturing environment [4]. Simple Additive Weighing Method (SAW method), Weighted Product Method (WPM) are the most popular techniques among all MADM methods. Analytical Hierarchy Process (AHP), TOPSIS (Technique for Order Preference by Similarity to Ideal Solution) method and its variants are also used here to observe the preference.

\section{Results and Discussions}


Based on the data in Table 1, prepare Table 2 with normalized data of attributes based on beneficiary and non beneficiary variables. A comparative study by varying weighting factors in the selection of particular alternate has also been done with in section 4.1 and 4.2.

Table 2. Normalized data table of attributes.

\begin{tabular}{|c|c|c|c|c|c|c|c|c|c|c|c|}
\hline S.No & Material & $\begin{array}{l}\text { Density } \\
\left(\mathrm{g} / \mathrm{cm}^{3}\right)\end{array}$ & $\begin{array}{c}\text { Thermal } \\
\text { Conductivity } \\
(\mathrm{W} / \mathrm{mK})\end{array}$ & $\begin{array}{l}\text { UTS } \\
\text { (Mpa) }\end{array}$ & $\begin{array}{l}\text { YTS } \\
\text { (Mpa) }\end{array}$ & $\begin{array}{c}\text { Fatigue } \\
\text { Strength } \\
\text { (Mpa) }\end{array}$ & $\underset{(J)}{\operatorname{Impact}}$ & $\begin{array}{l}\text { Hardness } \\
(\mathrm{BHN})\end{array}$ & $\begin{array}{c}\% \\
\text { Elongation } \\
\text { in } 50 \mathrm{~mm}\end{array}$ & $\begin{array}{c}\text { Specific } \\
\text { Heat } \\
\left(\mathrm{J} / \mathrm{g}-{ }^{\circ} \mathrm{C}\right)\end{array}$ & $\begin{array}{l}\text { Coeff . of } \\
\text { Thermal } \\
\text { Expansion } \\
(\mu \mathrm{m} / \mathrm{m}-\mathrm{C})\end{array}$ \\
\hline 1 & AZ91 & 0.9779 & 0.5959 & 0.7797 & 0.7500 & 1.0000 & 0.6279 & 0.8400 & 1.0000 & 1.0000 & 1.0000 \\
\hline 2 & AM60 & 0.9888 & 0.5082 & 0.8169 & 0.6550 & 0.8247 & 0.6512 & 0.8667 & 0.2308 & 0.8000 & 1.0000 \\
\hline 3 & AM50 & 1.0000 & 0.5328 & 0.7729 & 0.6200 & 0.7732 & 0.5814 & 0.8000 & 0.2000 & 0.7843 & 1.0000 \\
\hline 4 & AZ31 & 1.0000 & 0.7869 & 0.8814 & 1.0000 & 0.9278 & 1.0000 & 0.6533 & 0.2000 & 0.8000 & 1.0000 \\
\hline 5 & ZE41 & 0.9620 & 0.9262 & 0.6949 & 0.7000 & 0.6495 & 0.3256 & 0.8267 & 0.8571 & 0.8000 & 1.0000 \\
\hline 6 & EZ33 & 0.9833 & 0.8156 & 0.6780 & 0.7000 & 0.4124 & 0.1581 & 0.6667 & 0.9677 & 0.7692 & 0.9848 \\
\hline 7 & ZE63 & 0.9465 & 0.8934 & 1.0000 & 0.9500 & 0.8144 & 0.5349 & 1.0000 & 0.4286 & 0.8333 & 0.9630 \\
\hline 8 & ZC63 & 0.9465 & 1.0000 & 0.7119 & 0.6250 & 0.9588 & 0.2907 & 0.8000 & 0.6667 & 0.8000 & 1.0000 \\
\hline
\end{tabular}

\subsection{Attributes with equal importance - Equal weighting factors - Mean weighting method}

This section discusses all the properties of the material with equal importance, so that the decision maker consider on each individual property with the same importance. There are ten attributes such that the weightage factor for each attribute is $1 / 10=0.1$.

Table 3. The weigthage given to each attribute.

\begin{tabular}{cccccccccc}
\hline Attribute & Attribute & Attribute & Attribute & Attribute & Attribute & Attribute & Attribute & Attribute & Attribute \\
1 & 2 & 3 & 4 & 5 & 6 & 7 & 8 & 9 & 10 \\
\hline 0.1 & 0.1 & 0.1 & 0.1 & 0.1 & 0.1 & 0.1 & 0.1 & 0.1 & 0.1 \\
\hline
\end{tabular}

After identifying the suitable weights, apply different schemes of MADM methods and using the data of table 2 and table 3, evaluate the measure of performance. A Simple Additive Method (SAW method) approach of calculating measure of performance (mop) for alternate 1 is shown below.

$$
\mathrm{P}_{\mathrm{i}}=\sum_{j=1}^{m} w_{j} m_{i j}
$$

Where

$P_{i}$ is performance score of each alternate

$\mathrm{w}_{\mathrm{j}}$ is weighting factor of the particular attribute

$\mathrm{m}_{\mathrm{ij}}$ Normal is a normalized matrix of basic table.

\section{Alternate 1:}

$0.1 \times 0.9779+0.1 \times 0.5959+0.1 \times 0.7797+0.1 \times 0.7500+0.1 \times 1+0.1 \times 0.6279+0.1 \times 0.8400+0.1 \times 1+$ $0.1 \times 1+0.1 \times 1=0.85714$.

Similarly, the performance scores of each alternate can be calculated. Table 4 gives the overall performance scores to each alternatives by SAW method. 
Table 4. Performance score and ranking by SAW Method.

\begin{tabular}{cccc}
\hline S.No & Materials & Score & Rank to select the material \\
\hline 1 & AZ91 & 0.8571 & 1 \\
2 & AM60 & 0.7342 & 7 \\
3 & AM50 & 0.7065 & 4 \\
4 & AZ31 & 0.8249 & 8 \\
5 & ZE41 & 0.7742 & 5 \\
6 & EZ33 & 0.7146 & 2 \\
7 & ZE63 & 0.8364 & 6 \\
8 & ZC63 & 0.7800 & 3 \\
\hline
\end{tabular}

Vast literature is available for the other proposed MADM method principles, formulas and examples [4] [9]. A MATLAB program has been developed by using the formulae of the methods to calculate measure of performance. Table 5 provides the information on Performance score of each alternate by SAW method, WPM method, AHP method, Multiplicative AHP Method and TOPSIS method and one of its variants. Based on Performance scores obtained by the methods, each alternate is ranked and the summarized data is shown in table 6. AZ91 is a good choice material among the compared magnesium alloys with the given properties to suit for automobile wheels when equal weightage was given to all attributes.

Table 5. Performance scores of each alternate by MADM methods.

\begin{tabular}{cccccccc}
\hline S.No & Material & $\begin{array}{c}\text { SAW } \\
\text { Method }\end{array}$ & $\begin{array}{c}\text { WPM } \\
\text { Method }\end{array}$ & $\begin{array}{c}\text { AHP } \\
\text { Method }\end{array}$ & $\begin{array}{c}\text { Multiplicative } \\
\text { AHP method }\end{array}$ & $\begin{array}{c}\text { TOPSIS } \\
\text { method }\end{array}$ & $\begin{array}{c}\text { Modified } \\
\text { TOPSIS } \\
\text { Method }\end{array}$ \\
\hline 1 & AZ91 & 0.8571 & 0.8423 & 0.1407 & 0.1377 & 0.6433 & 0.6433 \\
2 & AM60 & 0.7342 & 0.6861 & 0.1167 & 0.1122 & 0.4156 & 0.4156 \\
3 & AM50 & 0.7065 & 0.6544 & 0.1115 & 0.1070 & 0.3385 & 0.3385 \\
4 & AZ31 & 0.8249 & 0.7634 & 0.1342 & 0.1248 & 0.5541 & 0.5541 \\
5 & ZE41 & 0.7742 & 0.7440 & 0.1246 & 0.1216 & 0.5022 & 0.5022 \\
6 & EZ33 & 0.7146 & 0.6433 & 0.1144 & 0.1052 & 0.4227 & 0.4227 \\
7 & ZE63 & 0.8364 & 0.8092 & 0.1338 & 0.1323 & 0.6035 & 0.6035 \\
8 & ZC63 & 0.7800 & 0.7413 & 0.1241 & 0.1212 & 0.5088 & 0.5088 \\
\hline
\end{tabular}

Table 6. Selection preference of each alternate based on mop calculated.

\begin{tabular}{cccccc}
\hline \multicolumn{7}{c}{ Ranking Structure } \\
\hline $\begin{array}{c}\text { SAW } \\
\text { Method }\end{array}$ & $\begin{array}{c}\text { WPM } \\
\text { Method }\end{array}$ & $\begin{array}{c}\text { AHP } \\
\text { Method }\end{array}$ & $\begin{array}{c}\text { Multiplicative } \\
\text { AHP method }\end{array}$ & $\begin{array}{c}\text { TOPSIS } \\
\text { method }\end{array}$ & $\begin{array}{c}\text { Modified } \\
\text { TOPSIS Method }\end{array}$ \\
\hline 1 & 1 & 1 & 1 & 1 & 1 \\
7 & 7 & 4 & 7 & 7 & 7 \\
4 & 4 & 7 & 4 & 4 & 4 \\
8 & 5 & 5 & 5 & 8 & 8 \\
5 & 8 & 8 & 8 & 5 & 5 \\
2 & 2 & 2 & 2 & 6 & 6 \\
6 & 3 & 6 & 3 & 2 & 2 \\
3 & 6 & 3 & 6 & 3 & 3 \\
\hline
\end{tabular}




\subsection{Attributes with un equal importance - different weighting factors}

\subsubsection{Randomized weighing method}

It is not always preferable to give equal importance to all the attributes. Weightage factors are given to indicate the relative importance or impact of that alternate in the group. The purpose of assigning weightage factors is to help in measuring an accurate overall performance rating. So the decision maker has to repeat different experiments and test its validity. Hence a study has been made with different weightage factors given to material properties and its influence on the proposed problem. As mentioned earlier, to reduce the mass of an automobile, one has to look for lower density materials. Different weighatge factors were considered such that the density has more weightage followed by all mechanical Properties with respective weight age and thermal properties with same weightage. The detailed weightage factors are shown in Table 7.

Table 7. The weigths given to each attribute.

\begin{tabular}{cccccccccc}
\hline Density & $\begin{array}{l}\text { Thermal } \\
\text { Conductivity }\end{array}$ & UTS & YTS & $\begin{array}{l}\text { Fatigue } \\
\text { Strength }\end{array}$ & Impact & Hardness & $\begin{array}{l}\text { \% } \\
\text { Elongation } \\
\text { in 50 mm }\end{array}$ & $\begin{array}{l}\text { Specific } \\
\text { Heat }\end{array}$ & $\begin{array}{l}\text { Coeff . of } \\
\text { Thermal } \\
\text { Expansion }\end{array}$ \\
\hline 0.2 & 0.0666 & 0.1 & 0.1 & 0.1 & 0.1 & 0.1 & 0.1 & 0.0666 & 0.0666 \\
\hline
\end{tabular}

Similar to an earlier section, the performance scores of each alternative are calculated by different methods and given in Table 8, while the ranks given to the materials are shown in Table 9.

Table 8. Performance scores of each alternate by MADM methods with Different Weights.

\begin{tabular}{cccccccc}
\hline S.No & Material & $\begin{array}{c}\text { SAW } \\
\text { Method }\end{array}$ & $\begin{array}{c}\text { WPM } \\
\text { Method }\end{array}$ & $\begin{array}{c}\text { AHP } \\
\text { Method }\end{array}$ & $\begin{array}{c}\text { Multiplicative } \\
\text { AHP method }\end{array}$ & $\begin{array}{c}\text { TOPSIS } \\
\text { method }\end{array}$ & $\begin{array}{c}\text { Modified } \\
\text { TOPSIS } \\
\text { Method }\end{array}$ \\
\hline 1 & AZ91 & 0.8684 & 0.8550 & 0.1407 & 0.1379 & 0.6621 & 0.6542 \\
2 & AM60 & 0.7562 & 0.7062 & 0.1183 & 0.1139 & 0.4301 & 0.4239 \\
3 & AM50 & 0.7292 & 0.6737 & 0.1132 & 0.1087 & 0.3485 & 0.3441 \\
4 & AZ31 & 0.8386 & 0.7752 & 0.1344 & 0.1250 & 0.5556 & 0.5549 \\
5 & ZE41 & 0.7795 & 0.7485 & 0.1236 & 0.1207 & 0.4931 & 0.4969 \\
6 & EZ33 & 0.7262 & 0.6526 & 0.1145 & 0.1053 & 0.4192 & 0.4205 \\
7 & ZE63 & 0.8414 & 0.8137 & 0.1328 & 0.1313 & 0.5977 & 0.6004 \\
8 & ZC63 & 0.7813 & 0.7427 & 0.1225 & 0.1198 & 0.4960 & 0.5015 \\
\hline
\end{tabular}

Table 9. Selection preference of each alternate based on mop with Different Weights.

\begin{tabular}{cccccc}
\hline SAW Method & WPM Method & AHP Method & $\begin{array}{c}\text { Multiplicative } \\
\text { AHP method }\end{array}$ & $\begin{array}{c}\text { TOPSIS } \\
\text { method }\end{array}$ & $\begin{array}{c}\text { Modified TOPSIS } \\
\text { Method }\end{array}$ \\
\hline 1 & 1 & 1 & 1 & 1 & 1 \\
7 & 7 & 4 & 7 & 7 & 7 \\
4 & 4 & 7 & 4 & 4 & 4 \\
8 & 5 & 5 & 5 & 8 & 8 \\
5 & 8 & 8 & 8 & 5 & 2 \\
2 & 2 & 2 & 2 & 2 & 6 \\
3 & 3 & 6 & 3 & 6 & 3 \\
\hline
\end{tabular}




\subsubsection{Entropy based weighting method}

It is not always the case to go for randomized weights all the time and to repeat the experiment till the decision maker has satisfied. Entropy based weighting method is highly reliable information measurement method in achieving the weights with accuracy [12]. In subjective weighting and objective weighting methods of entropy, the subjective weighting is based on decision maker's expertise and judgment, where as the objective weighting is based on mathematical computation. The objective weighting is particularly applicable where subjective weights cannot be reliable. Entropy methods are popular in obtaining the weights of an MADM problem by reducing Decision Makers experiments as much as possible. These also helpful in identifying the weights to attributes in less time.

In entropy method, the attributes with performance rating differ each other has higher importance in the problem that is the attribute is considered with lower preference if all the other materials have similar performance rating to the particular attribute. The greater the value of the entropy corresponding to the particular attribute implies the smaller attribute's weight and the less power of that attribute in decision making process. Entropy method consists of the following steps to evaluate the weights [12-13]. The weighting factors were calculated by the formulae and tabulated below shown in Table 10.

1. Normalize the Decision Matrix to eliminate anomalies with different measurement units and scales. $X_{\mathrm{ij}}$ is the original decision matrix.

$$
P_{i j}=\frac{x_{i j}}{\sum_{i=1}^{m} x_{i j}}
$$

2. After normalized the decision matrix, calculate the entropy values $e_{j}$ as

$$
e_{j}=-k \sum_{j=1}^{n} p_{i j} \ln p_{i j}
$$

Where $\mathrm{k}$ is a constant, let $\mathrm{k}=(\ln (m))^{-1}$

3. The degree of divergence $d$ of each criterion can be calculated as

$$
d_{j}=1-e_{j}
$$

The value $d_{j}$ represents the inherent contrast intensity of $\mathrm{C}_{\mathrm{j}}$.

Table 10. The weightings given to each attribute using entropy method.

\begin{tabular}{cccccccccc}
\hline Density & $\begin{array}{l}\text { Thermal } \\
\text { Conductivity }\end{array}$ & UTS & YTS & $\begin{array}{l}\text { Fatigue } \\
\text { Strength }\end{array}$ & Impact & Hardness & $\begin{array}{l}\% \\
\text { Elongation } \\
\text { in 50 mm }\end{array}$ & $\begin{array}{l}\text { Specific } \\
\text { Heat }\end{array}$ & $\begin{array}{l}\text { Coeff } \\
\text { Thermal of } \\
\text { Expansion }\end{array}$ \\
\hline 0.0005 & 0.0690 & 0.0194 & 0.0391 & 0.0691 & 0.2838 & 0.0203 & 0.4919 & 0.0067 & 0.0002 \\
\hline
\end{tabular}

The scores of each alternate are calculated by entropy proposed weightages given in table 11 while the ranks based on performance scores in Table 12 . 
Table 11. Performance scores of each alternate by MADM methods with entropy based Weights.

\begin{tabular}{cccccccc}
\hline S.No & Material & $\begin{array}{c}\text { SAW } \\
\text { Method }\end{array}$ & $\begin{array}{c}\text { WPM } \\
\text { Method }\end{array}$ & $\begin{array}{c}\text { AHP } \\
\text { Method }\end{array}$ & $\begin{array}{c}\text { Multiplicative } \\
\text { AHP method }\end{array}$ & $\begin{array}{c}\text { TOPSIS } \\
\text { method }\end{array}$ & $\begin{array}{c}\text { Modified } \\
\text { TOPSIS } \\
\text { Method }\end{array}$ \\
\hline 1 & AZ91 & 0.8492 & 0.8291 & 0.1795 & 0.1741 & 0.7806 & 0.7270 \\
2 & AM60 & 0.4555 & 0.3954 & 0.0944 & 0.0830 & 0.3268 & 0.3751 \\
3 & AM50 & 0.4150 & 0.3547 & 0.0855 & 0.0745 & 0.2426 & 0.2925 \\
4 & AZ31 & 0.5761 & 0.4378 & 0.1209 & 0.0919 & 0.4015 & 0.4749 \\
5 & ZE41 & 0.6865 & 0.6340 & 0.1426 & 0.1331 & 0.6432 & 0.5779 \\
6 & EZ33 & 0.6656 & 0.5240 & 0.1387 & 0.1100 & 0.5964 & 0.5222 \\
7 & ZE63 & 0.5637 & 0.5382 & 0.1151 & 0.1130 & 0.5965 & 0.5777 \\
8 & ZC63 & 0.6062 & 0.5577 & 0.1233 & 0.1171 & 0.6065 & 0.5494 \\
\hline
\end{tabular}

Table 12. Selection preference of each alternate based on mop with entropy Weights.

\begin{tabular}{cccccc}
\hline \multicolumn{6}{c}{ Ranking Structure } \\
\hline $\begin{array}{c}\text { SAW } \\
\text { Method }\end{array}$ & WPM Method & AHP Method & $\begin{array}{c}\text { Multiplicative } \\
\text { AHP method }\end{array}$ & $\begin{array}{c}\text { TOPSIS } \\
\text { method }\end{array}$ & $\begin{array}{c}\text { Modified } \\
\text { TOPSIS } \\
\text { Method }\end{array}$ \\
\hline 1 & 1 & 1 & 1 & 1 & 1 \\
5 & 5 & 5 & 5 & 5 & 5 \\
6 & 8 & 6 & 8 & 8 & 7 \\
8 & 7 & 8 & 7 & 7 & 8 \\
4 & 6 & 4 & 6 & 6 & 6 \\
7 & 4 & 7 & 4 & 4 & 4 \\
2 & 2 & 2 & 2 & 2 & 2 \\
3 & 3 & 3 & 3 & 3 & 3 \\
\hline
\end{tabular}

Figure 1, 2 and 3 shows the summary of weightage factors influence in selecting the material. It has been clear that the ranking structure proposed by all the methods to the alternates is not same. Each method having its own criterion and also the different weightage factors to attributes contributed in different ranking scenarios. AZ91 is superior to the other materials considered and ranked high in all conditions discussed.

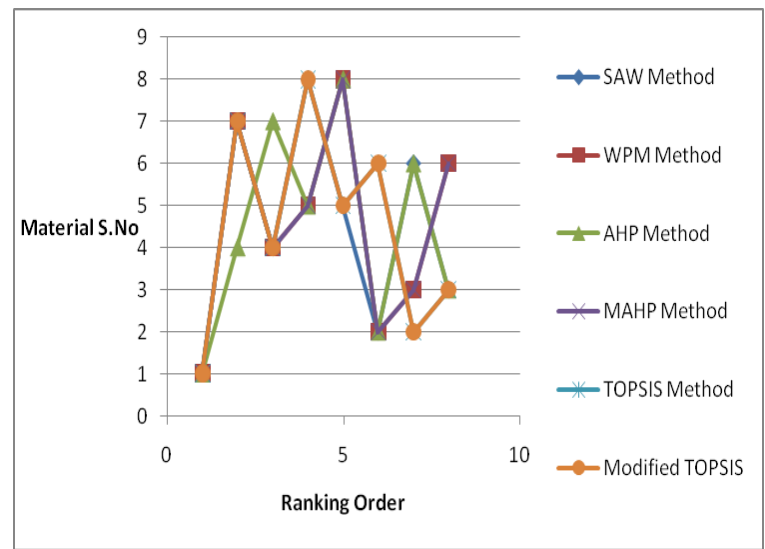

Fig 1. Ranking to materials with same weightings 


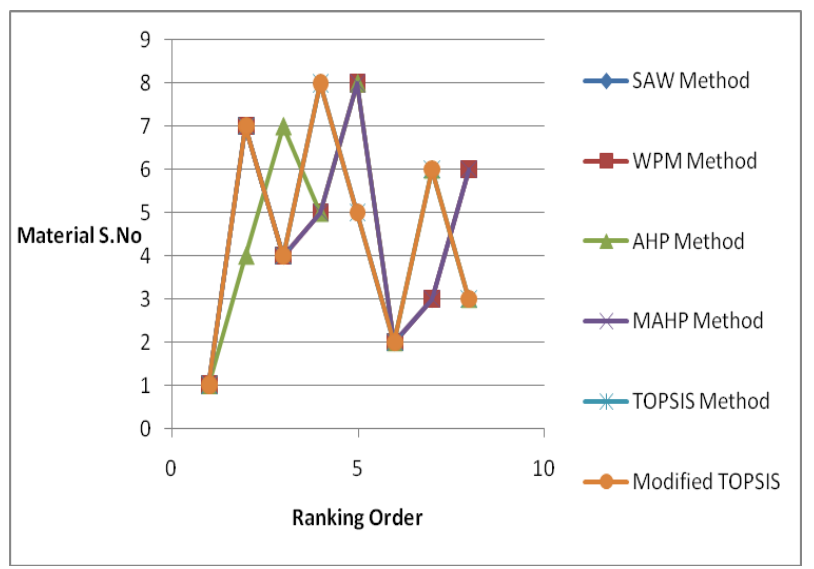

Fig 2. Ranking to materials with Randomized weightings

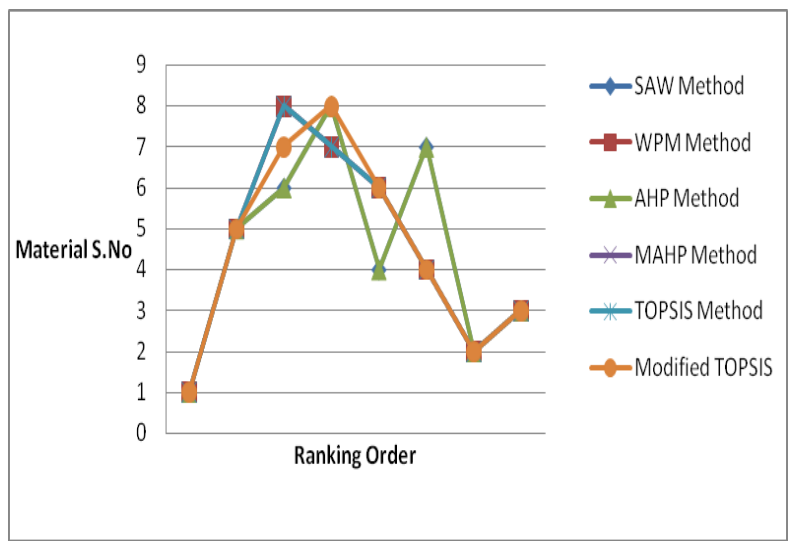

Fig 3. Ranking to materials with entropy based weightings

\section{Conclusions}

This paper proposes the application of a few MADM methods to Material Selection problem. The implementation of these algorithms given a systematic and logical solution to material selection problem. Wegihtage factors influence has also been discussed. When the weight factors are changed, the order of preference has been found to be changed. Each method suggests its own selection criterion, but finally it is the choice of decision maker to go with. AZ 91 is a good choice of Magnesium alloy material for the given problem.

\section{References}

[1] Nicholas Lutsey, "Review of technical literature and trends related to automobile mass-reduction technology", UCD-ITS-RR-10-10, Working Paper Series, Institute of Transportation Studies, University of California, Davis, May 2010. http://www.escholarship.org/uc/item/9t04t94w.pdf;origin=repeccitec 
[2] E. Aghion, B. Bronfin, H. Friedrich and Z. Rubinovich, "The Environmental Impact Of New Magnesium Alloys On The Transportation Industry", Magnesium Technology Edited by Alan A. Luo TMS (The Minerals, Metals \& Materials Society), 2004, pp: 167-172.

[3] Musfirah A.H, Jaharah A.G, "Magnesium and Aluminum Alloys in Automotive Industry", Journal of Applied Sciences Research, 8(9): 4865-4875, 2012, ISSN 1819-544X

[4] R. Venkata Rao , "Decsion Making in the Manufacturing Environment using Graph Theory and Fuzzy Multiple attribute Decision Making Methods”,Springer - Verlag London Limited 2007.

[5] R. V. Rao \& J. P. Davim, "A decision-making framework model for material selection using a combined multiple attribute decision-making method", Int J Adv Manuf Technol (2008) 35: 751-760 DOI 10.1007/s00170-006-0752-7.

[6] Dipali Rai, Goutam Kumar Jha, Prasenjit Chatterjee, Shankar Chakraborty, "Material Selection in Manufacturing Environment Using Compromise Ranking and Regret Theory-based Compromise Ranking Methods: A Comparative Study”, Universal Journal of Materials Science 1(2): 69-77, 2013.

[7] Ali Jahan, Kevin L Edwards, "Multi criteria decision analysis for supporting the selection of Engineering Materials in Product Design”, Butterworth-Heinemann, 2013.

[8] BGN Satya Prasad, M Anil kumar, "Topology Optimization of Alloy Wheel", Altair technology conference, India, 2013, pp: 1-7.

[9] D.Sameer Kumar, S. Radhika, K.N.S. Suman, "MADM Methods for Finding The Right Personnel in Academic Institutions", International Journal of u- and e- Service, Science and Technology Vol.6, No.5 (2013), pp.133-144 http://dx.doi.org/10.14257/ijunesst.2013.6.5.12

[10] L. Cizek et al., "Mechanical Properties of the model casting magenseium alloy AZ91 ”, $11^{\text {th }}$ international scientific conference - Achievements in Mechanical and materials Engineering, AMME 2002, pp 47 50 ,http://www.journalamme.org/papers_amme02/1112.pdf.

[11] Siobhan Fleming, "An Overview of Magnesium based Alloys for Aerospace and Automotive Applications, "A Project report submitted for Master of Engineering In Mechanical Engineering, Rensselaer $\begin{array}{llll}\text { Polytechnic Institute Aurtford, } & \text { CT }\end{array}$ http://www.ewp.rpi.edu/hartford/ ernesto/SPR/Fleming-FinalReport.pdf

[12] Kshitij Dashore, Shashank Singh Pawar, Nagendra Sohani, Devendra Singh Verma, "Product Evaluation Using Entropy and Multi Criteria Decision Making Methods", International Journal of Engineering Trends and Technology (IJETT) - Volume4 Issue5- May 2013 pp : 2183-2187

[13] Farhad Hosseinzadeh Lotfi and Reza Fallahnejad, "Imprecise Shannon's Entropy and Multi Attribute Decision Making”, Entropy 2010, 12, 53-62; doi:10.3390/e12010053

[14] "Data Sheet of AZ91", http://www.matweb.com/search/datasheet.aspx?MatGUID=07baafbb9c364fb18fd413bceced867f

[15] "Data Sheet of AZ31", http://www.matweb.com/search/DataSheet.aspx?MatGUID=5a005487e02e4e18b894b7867c3772f4

[16] "Data Sheet of AM60", http://www.matweb.com/search/DataSheet.aspx?MatGUID=9d88870cabe84aad823bcfed0b9ce00f

[17] "Data Sheet of AM50", http://www.matweb.com/search/DataSheet.aspx?MatGUID=a39cbb3aee8944259f0146ec21 cbbfcf

[18] "Electron ZE41", Data Sheet 452 A , Magnesium Electron North America Inc., http://www.magnesiumelektron.com/data/downloads/452A.pdf

[19] Nikhil Gupta, Dung D. Luong and Kyu Cho, "Magnesium Matrix Composite Foams-Density, Mechanical Properties, and Applications", Metals 2012, 2, 238-252; doi:10.3390/met2030238.

[20] Smithells Light Metals Handbook, Edited by E. A. Brandes and G. B. Brook, Butterworth-Heinemann , Reed Educational and Professional Publishing Ltd 1998.

[21] Information on http://www.makeitfrom.com.

[22] Information on http://www.azom.com 


\section{Author(s) Profile}

D. Sameer Kumar is presently working as Assistant professor in the Department of Mechanical Engineering, R.V.R. \& J.C. College of Engineering, Guntur. He has obtained his Masters degree with the specialization of CAD/CAM from Acharya Nagarjuna University, Guntur in 2007. He is pursuing research as external scholar in Andhra University, Visakhapatnam.

K.N.S. Suman has received Ph.D. degree from Andhra University, Visakhapatnam in 2006. His thesis was selected as best thesis during that year by Andhra University. He was the recipient of Senior Research Fellowships from UGC and CSIR. His research of interest include the preparation of Natural Composite Materials, analysis and their applications in Mechanical Engineering.

How to cite this paper: D.Sameer Kumar, K.N.S.Suman,"Selection of Magnesium Alloy by MADM Methods for Automobile Wheels", IJEM, vol.4, no.2, pp.31-41, 2014.DOI: 10.5815/ijem.2014.02.03 